

\title{
Sustainable Development and Innovation: Reviewing the Concept and Malaysian Participation
}

\author{
Patrick EtheRaj, Sazali Abd Wahab, Suzana Idayu Wati Osman, NurFadiah \\ Mohd Zawawi, Syed Ali Fazal
}

To Link this Article: http://dx.doi.org/10.6007/IJARBSS/v8-i9/4692

DOI: $10.6007 /$ IJARBSS/v8-i9/4692

Received: 19 August 2018, Revised: 12 Sept 2018, Accepted: 26 Sept 2018

Published Online: 18 October 2018

In-Text Citation: (EtheRaj, Wahab, Osman, Zawawi, \& Fazal, 2018)

To Cite this Article: EtheRaj, P., Wahab, S. A., Osman, S. I. W., Zawawi, N. M., \& Fazal, S. A. (2018). Sustainable Development and Innovation: Reviewing the Concept and Malaysian Participation. International Journal of Academic Research in Business and Social Sciences, 8(9), 1211-1226.

Copyright: (c) 2018 The Author(s)

Published by Human Resource Management Academic Research Society (www.hrmars.com)

This article is published under the Creative Commons Attribution (CC BY 4.0) license. Anyone may reproduce, distribute, translate and create derivative works of this article (for both commercial and non-commercial purposes), subject to full attribution to the original publication and authors. The full terms of this license may be seen

at: http://creativecommons.org/licences/by/4.0/legalcode

Vol. 8, No. 9, September 2018, Pg. 1211 - 1226

Full Terms \& Conditions of access and use can be found at http://hrmars.com/index.php/pages/detail/publication-ethics 


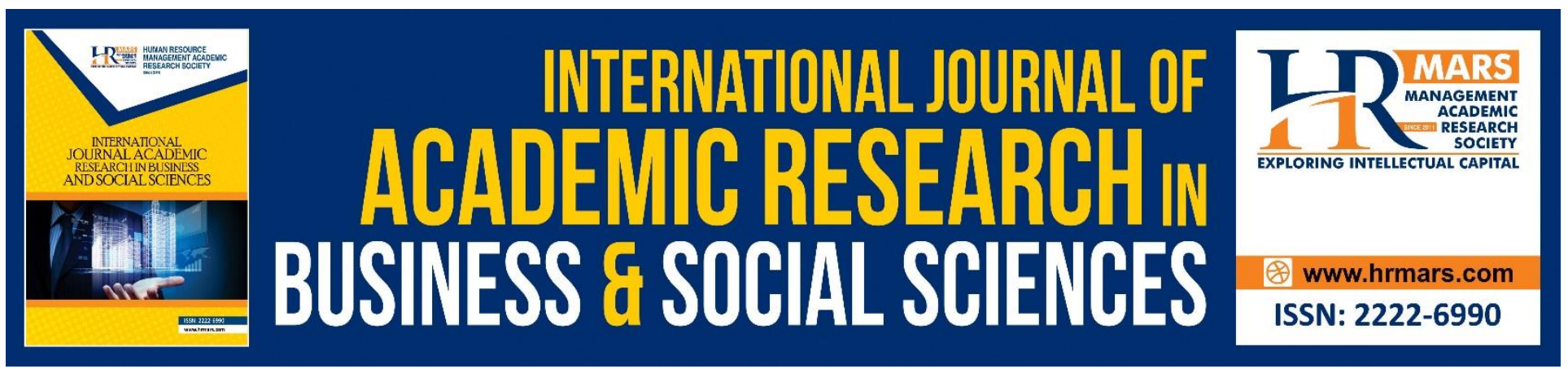

\title{
Sustainable Development and Innovation: Reviewing the Concept and Malaysian Participation
}

\author{
Patrick EtheRaj ${ }^{1}$, Sazali Abd Wahab², Suzana Idayu Wati Osman³, \\ NurFadiah Mohd Zawawi ${ }^{1}$, Syed Ali Fazal ${ }^{1}$ \\ ${ }^{1}$ Faculty of Entrepreneurship and Business, Universiti Malaysia Kelantan, Malaysia \\ 2 Putra Business School, Malaysia \\ ${ }^{3}$ Faculty of Administrative Science and Policy Studies, Universiti Teknologi MARA, Malaysia
}

\begin{abstract}
"Sustainable Development" has been the world agenda since 1972 which became official since Brundtland Commission's 1987 report. The world has united under one umbrella for the future of mother Earth with one common objective, 'the 2030 Agenda'. Malaysia's influence and active participation is since then and is more inclusive from 1996. In this new borderless era, sustainable development has become very important particularly in business. Innovation as the savior could lead the world towards sustainable development. United Nations (UN) acknowledged that innovation plays important role in sustainable development goals. This paper sets its focus in innovation and its contribution to sustainable development as the key objective; especially when integrated to business organizations through social, environmental and economic enterprises, bringing competitive innovation advantage to the firm, industry and nation as a whole.
\end{abstract}

Keywords: Sustainability, Sustainable Development, Innovation, Malaysia

\section{Introduction}

Mahatma Gandhi (1869-1948) mentions, "The future depends on what we do in the present". The sustainable development concept largely defined, accepted and used in these eras are from the Brundtland Commission's report 1987. "Sustainable Development" defined by this report: "the need to meet the demands and needs of present generation, but the present generation cannot compromise the need and ability of future generations to meet them themselves". Our Common Future as mentioned in Brundtland Commission's report 1987, also talks of the three pillars, which are economic growth, environmental protection, and social equality (Holden, Linnerud, \& Banister, 2014).

Sustainable development is not just achievable by new inventions, innovations, technological solutions, political agendas, regulations, law, and using financial instruments as solution tool alone. It starts with the people; the requirement and will to change especially in the mindset (think and 
INTERNATIONAL JOURNAL OF ACADEMIC RESEARCH IN BUSINESS AND SOCIAL SCIENCES Vol. 8, No. 9, Sept. 2018, E-ISSN: 2222-6990 @ 2018 HRMARS

act). This can only start with proper quality education especially emphasizing in the learning process in sustainable development starting from preschool level all the way to tertiary level not excluding proper training to all levels in social contexts. Education in sustainable development and for sustainable development enables us at present and future to be constructive with creativity to face challenges arising in sustainable development in the resilient societies (UNESCO, 2014).Starting from January 1, 2016, the outlined 17 goals in sustainable development goals (SDGs) of the Agenda2030 officially came in force and freely adopted by world political leaders since September 2015. It has a valid time line until 2030; the new sustainable development goals that apply to nations universally with shared a common goal globally for the future generations. Sustainable development viewed as a current business opportunity, issue, front, gateway, route, strategy, initiative, template and opportunity to multinational corporations and SME's who can have great influence and huge impacts, to economy, social and environment. Sustainable development creates opportunities in business, outlining new markets, new guidelines and new product requirements with new standards for users, all over the world. Success can be envisioned only come when these global goals are seen as our new impending opportunity to betterment of resource use and for business success as per required guidelines (United Nations Global Impact, 2016).

Can innovation serve, create to better and integrate business organizations through social, environmental, and economic enterprises under the umbrella of sustainable development? These are the challenges that been directed to management thoughtful and the practitioners since the new millennia era (Whiteman, Hope, \& Wadhams, 2013). Innovation through creativity relates to the problem solving process (viewed as the front-end through problem identifying and idea generation) and innovation through solutions related to problem solving through products (back end problem solving, focusing on acceptance and results) (Waples, Friedrich, \& Shelton, 2011). The 2030 Agenda connects the world community as a single unit to "achieve sustainable development in its original three dimensions version -economic, social and environmental, but in a more balanced scorecard, caring, inclusive and integrate manner". Achieving economic, social and environmental growth in unity is to achieve sustainable development; the questions remain in all our mind is "how" this integration is achievable, especially when need for each nation differ but for the sake of the whole world and future generation, all nations must then unite under one common objective. Integrating the three dimensions with a single common scorecard is a policy approach due to the huge widening income disparity and gaps in our community and a planet with no boundary, bringing the world as a single community. The 2030 Agenda is clear - "protect the planet from degradation, including through sustainable consumption and production. Sustainable development manages natural resources and mandates immediate action on climate change, for the need of present and future (United Nations ESCAP, 2015).

Seghezzo (2009) proposed an alternative sustainable development triangle, to include 'Place', 'Permanence', and 'Persons' as the new three Ps. (a) Place - physical and geographical location and includes cultural constructs that needs representation (b) Permanence - neglected in sustainable development debate, though we recognize only long-term success to our action, that is our real concern (c) Persons - people as individuals, community and society been excluded for very long period in notion of sustainable development.2030 agenda in sustainable development goal addresses issues and targets;(a) People (b) Planet (c) Prosperity (d) Peace and (e) Partnership. The definition, concept 
and influence on sustainable development through innovations have indeed evolved with positive critic. Ernesto Ciorra, Head of Innovation and Sustainability at Enel, "we are not sustainable unless we innovate, and in order to innovate, we have to be sustainable" (GRI, 2016). Sheer number of SMEs' across the world represent and will create massive impact within all business community, offering potential changes in the existing sustainable development landscape. SME offer the breakthrough in innovation opportunity only if we can team them across world in this global business world (Global Forum on Migration \& Development: Business Mechanism, 2016).

\section{Sustainable Development Goal (2030 Agenda)}

The goal in poverty eradication, agriculture and food security, energy, water, sanitation, and ultimately in climate change, links all the three in Science, Technology and Innovation with progress for people and planet. Sustainable development now faces its greatest challenge. Sustainable development achieved will advance Science, Technology and Innovation to achieve capably and achieve all sustainable development goals. Science, Technology and Innovation are not a stand from new technologies or new software, but also in mindset and attitude (Local and regional government members (UCLG, 2015). The expected outcomes from SDGs achievements are outlined in Table 1 below.

Table 1: Expected outcomes from SDGs achievements

\begin{tabular}{|c|c|}
\hline Item & SDGs achievement \\
\hline 1 & Successful networking globally and matchmaking for a suitable environment, \\
\hline 2 & Quality and respect to science \\
\hline 3 & Transparency and openness \\
\hline 4 & Respect for intellectual rights \\
\hline 5 & $\begin{array}{l}\text { Joint, sharing and integrated working relationship (avoid duplications and for business } \\
\text { intelligence) }\end{array}$ \\
\hline 6 & Grants and partnership, \\
\hline 7 & Library for information, experiences sharing and best practices \\
\hline 8 & $\begin{array}{l}\text { Public policy related to internet governance for exchange and sharing of information using best } \\
\text { practices }\end{array}$ \\
\hline 9 & Internet services more affordable and also more accessible, more so in developing nations, \\
\hline 10 & Support by government, more so by the Department of Economic and Social Affairs \\
\hline 11 & Innovative interactions - innovators and policymakers \\
\hline 12 & Governments frameworks and road maps for Science, Technology and Innovation initiatives \\
\hline 13 & $\begin{array}{l}\text { Science, Technology and Innovation in terms of education, skills and training, capacity building } \\
\text { and good public policy in fostering innovation }\end{array}$ \\
\hline 14 & Reaching out to all stake holders, more so to the middle and lower income group \\
\hline 15 & $\begin{array}{l}\text { Investment in people or human resources, scientific research and dissemination or sharing } \\
\text { information in a common platform }\end{array}$ \\
\hline 16 & $\begin{array}{l}\text { Reaching out to the youth in Science, Technology and Innovation and youth to use new } \\
\text { approaches and new perspectives in developing solutions to meet SDGs }\end{array}$ \\
\hline 17 & Empowering youth participants in policy process \\
\hline
\end{tabular}

Source: United Nations (2016) 
INTERNATIONAL JOURNAL OF ACADEMIC RESEARCH IN BUSINESS AND SOCIAL SCIENCES Vol. 8, No. 9, Sept. 2018, E-ISSN: 2222-6990 @ 2018 HRMARS

\section{Sustainable Development - The timeline}

The year 1962, was noted as the year when Rachel Carson's published "Silent Spring". This started a debate and as a point to start, a turning point to the key dimensions individually and in interconnections; listing the key three elements environment, economy and social well-being. Milestones since, have been many and the key ones listed after 1990 by Heather Creech, 2012 Director of International Institute for Sustainable Development. International institute for sustainable development, Canada established in 1990. Regional Environmental Centre, 1990, it was established for Central and Eastern Europe. Key objective was to challenge and battle environmental issues and with emphasis to engage the business community, governments and civil society. In 1991, Global Environment Facility established and restructured in 1994, for greater decision empowerment to developing countries with money in aid for working together in areas of biodiversity, climate change, drinking water, land, energy and pollutants. The business council for sustainable development, 1992 publishes changing course established for business involvement to promote sustainable development attitude (UCLG, 2015). The start of real serious effort by humankind started after the Burtland's 1987 report.

In the year 1992 Rio Earth Summit, a UN Conference on Environment and Development (UNCED) was held in Rio de Janeiro, agreements reached in that summit was on action plan Agenda 21, also known as the Rio Declaration. In 1995, World Summit for Social Development then held in Copenhagen, a first international commitment, calling for eradication of absolute poverty worldwide. In 1996, ISO 14001 started and adopted as international standard for corporate environmental management. In 2000, United Nations Millennium Development Goals, world leaders agrees on a time-bound with measurable goals to fight poverty, hunger, disease, illiteracy, environmental issue and gender discrimination with time line set and to end by 2015(United Nations, 2015b). In 2002, World Summit on sustainable development held in Johannesburg, marking 10 years since UNCED. Government lacks progress in climate issues and the way forward was that the summit promotes "partnerships" approach to sustainable development.

In 2005, Kyoto Protocol, on Green House Gas (GHG) emission reductions, and establishing Clean Development Mechanism (CDM) for countries with emissions reductions obligations until 2012. A legally binding goal was set among nations. In 2007, Montreal Protocol, on chemicals that deplete ozone, phasing-out hydro chlorofluorocarbons (HCFCs). In 2009 Copenhagen, nations fail to achieve new agreements, in greenhouse gas emissions reductions commitments beyond 2012. In 2012, Rio +20: 50 years after Silent Spring, 40 years after Stockholm and 20 years after the Earth Summit. The global community reconvenes to secure agreement on "greening" world economies through clean energy, decent jobs with more sustainable and fair use of resources. In 2015, to transform our world, 2030 agenda for sustainable development, created and agreed on new sustainable development goals with universal set of goals effective over the next 15 years. The sustainable development goals follows with a set time line that starts in 2016 and ends at 2030.Sustainable development goals expands Millennium Development Goals' outline (United Nations, 2015b).Millennium Development Goals (2001-2015) and the Sustainable Development Goals - 2030 Agenda (2016-2030), a global issue led by United Nations. Sustainable development goals are beyond traditional development cooperation: (a) Ending hunger (b) Reducing maternal deaths, and (c) Ensuring all childgets educated. Sustainable development goals also pay attention to other deliverables in global public goods - energy 
INTERNATIONAL JOURNAL OF ACADEMIC RESEARCH IN BUSINESS AND SOCIAL SCIENCES Vol. 8, No. 9, Sept. 2018, E-ISSN: 2222-6990 @ 2018 HRMARS

access, resilient infrastructure, sustainable oceans, and inclusive economic growth (United Nations, 2015b). Policy making in terms of global ambition starts here. Sustainable development goals program has 17 goals and 169 targets. The implementation, financing and monitoring and measurability will be tough and complex, for both developed and developing nations (Kamphof, Spitz, \& Boonstoppel, 2015).

Local governments, industry organizations, non-governmental organizations, firms and their associations are actors in this global partnership towards sustainable development goals realization(United Nations, 2015a).Local governments are not mere implementers but the stakeholders for sustainable development goals accomplishment; they are the policy makers to their actual surrounding, the catalysts for realizing impending change and the link between the sustainable development goals global desire and local communities (UCLG, 2015). The gaps seen and accepted on sustainable development, as mentioned by the then UN Secretary-General Ban Ki on $6^{\text {th }}$ Jun, 2016, also records that innovation is critical for sustainable development, through use of science and technology only then the assets can deliver the sustainable development delivery goals. The sustainable development goals are voluntary and free will in framework, no legal binding or report for on progress, the people, society and non-government organizations need to be the reminder for the governments (Pope Francis Laudato $\left.\mathrm{Si}^{\prime} 139,2015\right)$. We, the people of this world are invited to participate and act through the global conversation for our future and planet through; (a) Make contact and connections, (b) Build the bridge to show people power and (c) Be real to strengthen participation (Francis, 2015).

The policy makers and implementers must have correct and precise knowledge and awareness on sustainable development and in process of sustainable development with knowledge to execute with clarity on (a) what to do (b) how to do (c) when to do (d) where to do and (e) done by whom. It is then (a) to educate all policy maker and implementers on sustainable development by constant meetings and trainings, (b) new product and technology acceptance for ensuring latest and correct with latest updated data, (c) Establish partnership and sectorial participative consultation (d) Promote sustainable development and environmental culture through awareness campaign and training including problem highlights (e) facilitate information transformation using public institutions between the different variable actors (g) Develop outlets and tools for implementation and effective outreach (via communication) and (h) Training all variable actors in the project technical framework for common knowledge and objective and implementation success and consequences (Rafika, Rym, Souad, \& Youcef, 2016). Targets of sustainable development goals are related to (a)People (b) Planet (c) Prosperity(d) Peace and (e) Partnership.

\section{Sustainable Development - Malaysian Time Line}

Malaysia's active participation in sustainable development started since Seventh Malaysia Plan in 1996. The Seventh Malaysia Plan mentions the requirements to strengthen the environmental and information database systems to "...clearly delineate the relationship between the environment and sustainable development."(Economic Planning Unit, 2018). Malaysia follows the same concept and definition as stated in United Nations resolution (Abdulrazak \& Ahmad, 2014). Malaysia participates actively in international sustainable development program and activities, since the 13th session of the commission in New York starting since 2005. Malaysian participation in sustainable development 
INTERNATIONAL JOURNAL OF ACADEMIC RESEARCH IN BUSINESS AND SOCIAL SCIENCES Vol. 8, No. 9, Sept. 2018, E-ISSN: 2222-6990 @ 2018 HRMARS

is through(a) Malaysia National Development Policy - started with poverty eradication program since 1993 (b) National Conservation Policy - for environmental considerations including planning and management and as per sustainable development of Agenda 21(c) Malaysia National Vision Policy an equitable society through economic development and environmentally protection as sustainable development requirement (d) Malaysia Vision 2020 or "Wawasan 2020" - development through economic, but not neglecting political balance, social acceptance, spiritually respect, psychological and cultural understanding. The participation of Malaysia in these programs did manage to reduce poverty and stands below 5\% since 2005 (Shamsul, 2012).

To improve the standard of life and quality of rural communities through increasing access of basic physical infrastructure and social with quality under the National Key Result Areas is the Malaysian government effort since 2010 that focuses on three core and fundamental developments (a) Infrastructure (b) Human Capital and (c) Natural Resources. Protecting natural resource, protect ecosystem, water resources, natural forests, wild habitat, wildlife conservation, water source and biodiversity surrounding leading to climate resilience.Malaysia's public participation and awareness on environmental issues have very low participation (Radieah, Koshy, \& Ibrahim, 2015). The true sustainable development in decision-making must include elements integrated together for the project, nation and future (Kirsty et al., 2011).Malaysia is in her eleventh Malaysia Plan era 20162020, with the theme to achieve its own three goals of New Economic Model on high income, inclusivity and sustainability. "Anchoring Growth on People" and achievements are listed in Table 2 and Table 3.

Table 2: Malaysian achievement report on SDGs

\begin{tabular}{|c|c|c|}
\hline Item & SDG & Achievements \\
\hline \multirow[t]{2}{*}{1} & SDG $1 \&$ & Malaysia's success lays in poverty reduction from $49.3 \%$ in the 1970 era to $0.6 \%$ in \\
\hline & SDG 2 & 2014 and with no reported related to hunger; \\
\hline 2 & SDG 3 & $\begin{array}{l}\text { Child and maternal mortality rates prevail to of developed nations; small pox and } \\
\text { polio are eradicated endemic with reverse trend in the spread of HIV/AIDS. } \\
\text { Reductions from water-borne diseases, reductions in deaths from treatable children } \\
\text { base diseases and malaria. } 95 \% \text { of public health service subsidized (2015) }\end{array}$ \\
\hline 3 & $\begin{array}{l}\text { SDG } 4 \& \\
\text { SDG } 5\end{array}$ & $\begin{array}{l}\text { Education is compulsory with above } 90 \% \text { enrolment rates for both primary and } \\
\text { secondary schools, for both boys and girls with no gender biasness. } 48 \% \text { enrollment } \\
\text { for higher education in } 2012 \text { ( } 70 \% \text { higher than in } 2002 \text { ) in favor of girls }\end{array}$ \\
\hline 4 & SDG 6 & $\begin{array}{l}\text { Controlled supply at national level, exceeding } 95 \% \text { coverage for people and industry } \\
\text { for water, sanitation and electricity supply. }\end{array}$ \\
\hline 5 & $\& 16$ & $\begin{array}{l}\text { Available laws, regulations, policies and plans with constant update or protection } \\
\text { and towards better ensure ability in sustainable use of natural resource and assets. }\end{array}$ \\
\hline 6 & SDG 8 & Full employment since 1992; \\
\hline 7 & SDG 10 & $\begin{array}{l}\text { Broader middle class range with reduction in income disparity, Gini Coefficient from } \\
0.513(1970) \text { to } 0.401(2014) \text {. }\end{array}$ \\
\hline 8 & $\begin{array}{l}\text { SDG } 13, \\
14 \\
\& 17\end{array}$ & $\begin{array}{l}\text { Summary of } 2015: \text { 1) Above } 50 \% \text { forest cover 2) Above } 10.76 \% \text { as terrestrial } \\
\text { protected areas 3) Above } 1.06 \% \text { as marine protected area 4) } 33 \text { reduction in carbon } \\
\text { intensity (since 2009) and 5) New plans and increase in renewable energy capacity. }\end{array}$ \\
\hline
\end{tabular}

Source: Economic Planning Unit (2017) 
INTERNATIONAL JOURNAL OF ACADEMIC RESEARCH IN BUSINESS AND SOCIAL SCIENCES Vol. 8, No. 9, Sept. 2018, E-ISSN: 2222-6990 @ 2018 HRMARS

Table 3: Others remarkable achievements related to sustainable development

\begin{tabular}{|c|c|c|}
\hline Item & Field & Achievement \\
\hline a. & Infrastructure & $\begin{array}{l}\text { Over } 95 \% \text { coverage for treated water and sanitation facilities, and } 98.2 \% \\
\text { coverage of } 24 \text {-hour electricity supply at national level in } 2015 \text {. }\end{array}$ \\
\hline b. & $\begin{array}{l}\text { Justice } \quad \& \\
\text { Strong } \\
\text { Institutions }\end{array}$ & $\begin{array}{l}\text { Ranked } 55 \text { out of } 176 \text { countries in Corruption Perception Index; Ranked } 40 \text { out } \\
\text { of } 193 \text { countries in Online Service sub-index of the UN e-Government } \\
\text { Development Index (2016) }\end{array}$ \\
\hline c. & $\begin{array}{l}\text { SCP \& Climate } \\
\text { Change }\end{array}$ & $\begin{array}{l}\text { RM } 429 \text { millions of green government procurement since 2013; carbon intensity } \\
\text { of economy reduced by } 33 \% \text { since } 2009\end{array}$ \\
\hline d. & $\begin{array}{l}\text { Economy } \\
\text { \&Employment } \\
\text { Environmental } \\
\text { Endowment }\end{array}$ & $\begin{array}{l}\text { Sustained } 6.2 \% \text { per annum economic growth for } 50 \text { years. Full employment } \\
\text { since } 1992 . \text { Increase of female labour force participation rate to } 54.1 \% \text { (2015) } \\
\text { Malaysia participates in international transboundary conservation efforts, } \\
\text { namely, Heart of Borneo initiatives for forests and Coral Triangle Initiatives for } \\
\text { marine areas }\end{array}$ \\
\hline & Global Roles & $\begin{array}{l}\text { Shared development experience with } 31,000 \text { participants from } 142 \text { countries } \\
\text { through Malaysian Technical Cooperation Programme (2016); Strong partner in } \\
\text { the implementation of ASEAN Economic Community }\end{array}$ \\
\hline
\end{tabular}

Source: Economic Planning Unit (2017)

\section{Sustainable Development and Innovation: The Relationship}

"Vision 2050" leads the way in a world with 9 billion estimates; quality living, to use limited planet resource wisely by 2050" (World Business Council for Sustainable Development, 2010). Our society with huge appetite and demand with new consciousness has awakened the corporate business world to realize that the new appetite from the society's sustainable development hunger, fed and this helps the huge corporates to move away from risks and take opportunity from the created by this new demand (M. Porter \& Kramer, 2011). Corporations around the world are struggling with this new role, which is to meet the needs of the present generation without compromising the ability of the next generations to meet their own needs. Corporate social responsibility or to include sustainable development in multinational corporations are prominent feature that must be incorporated in business for society development to address good business ethics, social responsibility, global citizenship inclusivity, and belonging characters as stakeholder. New mega trends with global impacts and global commitment including financial obligations needed benefits to people and business have reshaped organizations frameworks, methods, rules, criteria and business models(Alessia, Sybil, \& Sue, 2009). This leads to multi-national corporations who are in position to create large-scale impacts related to innovation, wealth creation, inter and intra transfer technology, increase in productivity, and provide basic needs, to improve quality and standard of living, and life and living quality for global improvement including life span and health care, which are within the boundaries of sustainable development goals. Industry 4.0 when included enhances these desires and option, creating an added competitive advantage.

Sustainable development innovation is defined as a process where sustainable development considerations (environmental, social, and economic) are integrated into company systems from idea generation through to research \& development and commercialization" to reach the people (Boons, Montalvo, Quist, \& Wagner, 2013).These processes include new technologies, services and products 
INTERNATIONAL JOURNAL OF ACADEMIC RESEARCH IN BUSINESS AND SOCIAL SCIENCES Vol. 8, No. 9, Sept. 2018, E-ISSN: 2222-6990 @ 2018 HRMARS

including business models and organizational or firm structural models, i.e. distinctively in sustainable development innovations, with continues improved performance, "where such performance need to include other categories like ecological, social criteria and economic" (Carrillo-Hermosilla, Del Río, \& Könnölä, 2010). Sustainable development innovations include all innovations which must maintain or increase the current capital stock in comparison to past with no compromises (environmental, social, economic). Firm and entrepreneurs must try to remove internal negative and relating external effects using their innovations(Schaltegger \& Wagner, 2011), but in totality should produce "net positive" measurable effects (Ehrenfeld, 2008) in sustainability values related to social, economy and environment as a whole.

Effective and committed leadership will create ways to new performance uplift and leadership by example in firms economy by this millennium seeking to be including sustainable development(Waite, 2014). This requires creative works in innovation (Vinarski-Peretz \& Carmeli, 2011), and must cope to pressure of social and environmental issues (Leach et al., 2012). Historic context of innovation from both macro and a micro economic perspective (Hospers, 2005)and historic context of sustainable development since Brundtland Commission 1987, require a change in mindset with new leadership mentality, that is required to face this complex and dynamic phenomenon and to drive the much desired changes in sustainable development values though innovation (Waite, 2014). Innovation does serve and create better social, environmental, and economics value for a nation and enterprises (i.e. business organizations). These new challenges have drawn the attention and wisdom of researchers, management thinkers and practitioners (Whiteman et al., 2013). Innovations provides radically change to individuals, firm, and societies to relate individually and to relate with each another. Innovation changes course and path. Innovations is the fundamental reason for shrinking the society border through globalization, complex new interdependencies, worldwide borderless risks, natural resource usage and consumption, collapse in biodiversity, environmental changes and challenges, better health living style and an aging world population and more prominent urban living lifestyle (Motesharrei, Rivas, \& Kalnay, 2014).

This present academic work focuses on the complexity of sustainable development, where innovation viewed as the frontier for current and future of humankind. The challenges attributed by ignoring sustainable development in our life lead to multidisciplinary, immense and complex impact to humankind though multi-level social systems destructions (Hecht, Yang, Basnett, Padoch, \& Peluso, 2015). In this context of sustainable development and work, the theoretical eye from resource base view and technology acceptance model has contributed in the valuable understanding on sustainable development and innovation in Strategic Management alliance. Stakeholders of an organization both external and internal are becoming more involved to the core especially with involvement of innovation and knowledge intensive content away from labor-intensive processes leading to sustainable development achievement. All contribute positively to; (i) External stakeholders: (a) Customers (b) Suppliers (c) Competitors (d) Environment and (e) Society and (ii) Internal stakeholders: (a) Human Resource and (b) Shareholder (Shahbudin, Nejati, \& Amran, 2011).

Sustainable development merging with innovation related study intriguers' researchers(Kobayashi, Kato, Maezawa, \& Sano, 2011; Sánchez-Medina, Corbett, \& Toledo-López, 2011) and policy makers (OECD, 2011)with its relationships connected to competitive innovation advantage creation and sustainable firm performance. Researchers agree sustainable development innovation understood 
INTERNATIONAL JOURNAL OF ACADEMIC RESEARCH IN BUSINESS AND SOCIAL SCIENCES Vol. 8, No. 9, Sept. 2018, E-ISSN: 2222-6990 @ 2018 HRMARS

as "an innovation process incorporated in the firm's system that leads to improvement in sustainable development performance (environmental, social, and economic). Performance includes ecological/environmental, economic, and social criteria (Boons et al., 2013; Fritz \& Schiefer, 2008). Sustainable developments through innovation research have created awareness for policy-makers, government, firms, non-government organizations, users and producers (Raynolds, Murray, \& Wilkinson, 2007). Societal and environmental factors can be included positively for economic gains which leads to border shifting that business surrounding not aligned to market competition (A. Smith, Stirling, \& Berkhout, 2005), but new borders of sustainable development through innovation walls once merged in success creates superior competitive innovation advantage. Sustainable development through innovation simply leads to firm survival and existence, this would also lead to policy surveillances, science, technology and innovation capabilities to change and adapt to surroundings (Teece, Pisano, \& Shuen, 1997). Change in view, opinion and procedures lead to new growth of user's needs. Changes are inevitable but changes happen faster with huge improvements in information and communication technology, firm's face new competition through globalization, customization, and transformation (Chen, 2016).

Sustainable development through innovation is becoming important, evident, through the firm's choice in sustainability existence, user satisfaction, and Science Technology and Innovation improvement (Boer \& Gertsen, 2003). Sustainable development through innovation adds stepladder values and benefit value chain for firm to breathe and survive in borderless competitive surrounding globally (Lin \& Kuo, 2007). Firms maintain their competitive advantage through continuous improvement in process and product innovation to support business strategy (Smeds \& Boer, 2004). Sustainable development through innovation is important and indispensable even in literature studies or in practical works in a firm (Chen, 2016), this creates competitive innovation advantage. Innovation can also relate to beyond product and services. It can relate to quantitative innovations, sustainable development strategies, new material process and usage, new production methods, savings realization from act of use, optimization, new process and methods which are ecologicalfriendly can also relate to innovation, which in turn contribute to sustainable development goals effectively either directly or indirect associated methods. Standards, frameworks, associations and centers, International recognized and with self-regulatory incentives and initiatives, e.g. International Coalition for Sustainable Aviation. Sustainable Development Goals can be interconnected and prevalent that through achievement of an objective of a target, can then lead to fulfillment of other sustainable development goal and related targets. A clear example is seen in an electrification program (Solmecke, 2017) which can lead to new township, new community, improvement in communication, population wealth, new business, farming, agriculture, employment creation that can relate directly elimination of hunger and poverty. Life span of people will be enhanced with improvements in water quality, type of food availability, food quality, sanitation, medical treatment and medicine availability (Kooijman-van Dijk \& Clancy, 2010), all possible through innovation that can lead to access to modern technology that leads to facilitation of education and gender equality (Terrapon-Pfaff, Dienst, König, \& Ortiz, 2014).

Industry 4.0 first used in 2011 by Henning Kagermann, a strategic initiative defined as digital transformation involving manufacturing and technology platform, involving numerous and continuity in innovation and resulting in; Big Data/Analytics, internet of things, information technology, 
operational technology, artificial intelligence, robotics, cyber security, cloud, simulation, additive manufacturing (3D) and augmented reality. They innovation relate to data capture, manufacturing processes, production methods, connecting to technology and factories, linking machines with people, smart manufacturing, decentralization - self-optimization in systems use, digitization of supply chain and cyber-physical environment(i-Scoop, 2016). Industry 4.0 relate to (a) Strategy, (b) Leadership, (c) Governance, (c) Culture and (d) People. It relates and fosters with innovation and with economy growth through job creation, leading to income increase and better living standard. Industry 4.0 creates new models related to service industry associated with sustainable development business opportunity.

People constantly seek and pursue higher standard in living quality, this desire then applies pressure to deliver them. In the new millennium, these and more are constantly looked after by all, producing cheaper, better products whilst conserving utilization of resources, reduced energy consumption, reduced or no pollution and waste generation (Smith \& Ball, 2012)and it is just not a desire but an ambition that must be met. Operational efficiency must improve (M. G. Yang, 2013) and generate new competitive advantage in relativeness to other products, which are lagging and obsolete (C.-L. Yang, Lin, Chan, \& Sheu, 2010). This widens the understanding on the interlinked and direct implication of innovation through sustainable development in SME's in Malaysia, serving as a base for knowledge, commitment, importance and contribution of innovation - Sustainable development in Small Medium Enterprise (Mokthsim \& Salleh, 2014).

\section{Sustainable Development through Innovation and Competitive Innovation Advantage}

Resource base view and its fundamental values is that multinational firms and small medium enterprises achieves its competitive advantages through it is a superior internal resources, not through market or industry's demands and nature (Aziz \& Samad, 2016). Competitive advantages in a firm is established when it creates a benefit in and for a product or a process that creates success value positioning over competitors (Barney, 1991; Porter, 1980). Cost, product or service differentiation advantages are source of competitive advantages creating positioning (Porter, 2000). Researchers have studied innovation as independent variables and dependent variables of cost, quality, time and flexibility; the four dimensions of competitive advantage and innovation does have positive impact on competitive advantage(Abou-Moghli, Abdallah, \& Al Muala, 2012). Measurements of competitive advantages are measurable through dimensions of cost, perceived quality, period and time, and adoptability or flexibility activity (Bulankulama \& Khatibi, 2014). Sustainable development can be associated and linked to competitive advantages(Falkenberg \& Brunsæl, 2011; Gutierrez, Alcaraz, Susaeta, Suarez, \& Pin, 2015). Commitment and doing work related to sustainable development enhances competitive advantages of firm, building, image and brand that leads to differentiation from product, competition and competitors alike(Jones, Hillier, \& Comfort, 2014).

Sustainable development is a business issue, front, gateway, route, strategy, initiative or a template with a broad scope with huge impact, to economy, social and environment. The stakeholders: (a) employees, (b) customers, (c) consumers, (d) SC partners, (e) competitors, (f) investors, (g) lenders, (h) insurers, (i) non-governmental, (j) competitors (k) media, (l) government and (m) society to participate and, act for the goodwill of our own future and future generation (Hopkins et al., 2009).In 
INTERNATIONAL JOURNAL OF ACADEMIC RESEARCH IN BUSINESS AND SOCIAL SCIENCES Vol. 8, No. 9, Sept. 2018, E-ISSN: 2222-6990 @ 2018 HRMARS

summary, innovation when it merges successfully with sustainable development brings about competitive innovation advantage to the firm.

\section{Discussion and Conclusion}

Sustainable development relates to infrastructure, inclusive industrialization and innovation Key initiatives the focus on cradle-to-grave talent development and lifelong learning will improve labor productivity, deliver a higher skilled workforce, and create a virtuous cycle of job creation, growth, social development, green growth for sustainability and resilience to be a way of life. This will lead to strengthening food, water, and energy security, lower environmental risks, better well-being and quality of life andstrengthening infrastructure to support economic expansion. Eventually the growth will lead Malaysia in having access to basic amenities, connected through integrated transport and high-speed internet that will lead to new investment focusto lowering cost of business and enhancing competitiveness. Re-engineering economic growth for greater prosperity will ensure quality growth and international competitiveness. All economic sectors will migrate towards more knowledgeintensive and high value-added activities with greater productivity. Thegame changers; "Translating innovation to wealth" and "Embarking on Green Growth", National Policy on Science, Technology and Innovation (NPSTI) 2013-2020 and Strategic Information and Communications Technology (ICT) Roadmap are used in Malaysia to realize its goals in sustainable development.

Based on discussion, there is a general agreement that innovation is important for survival of firms in business and merging successfully with sustainable development brings implications related to competitive innovation advantage. This review relates innovation to sustainable development, impact and its' important. This review acknowledges the limited research, the need and requirement with greater futuristic understanding to generate new ideas for future research. Its implication and result is evident in firms, industry and nations, especially in Malaysia where the nation has taken innovation as key milestone and made huge progress to address sustainable development goals issues.

\section{Corresponding Author}

Patrick EtheRaj, PhD Candidate, Faculty of Entrepreneurship and Business, Universiti Malaysia Kelantan, Kota Bharu, Malaysia, Email: pat.nasmech@gmail.com.

\section{References}

Abdulrazak, S., \& Ahmad, F. S. (2014). Sustainable development: A Malaysian perspective. ProcediaSocial and Behavioral Sciences, 164, 237-241. https://doi.org/10.1016/i.sbspro.2014.11.072

Abou-Moghli, A. A., Al Abdallah, G. M., \& Al Muala, A. (2012). Impact of innovation on realizing competitive advantage in banking sector in Jordan. American Academic \& Scholarly Research Journal, 4(5), 1.

Alessia, D. A., Sybil, H., \& Sue, F. (2009). Corporate Social Responsibility and Sustainable Business A Guide to Leadership Tasks and Functions. North Carolina.

Aziz, N. N. A., \& Samad, S. (2016). Innovation and competitive advantage: Moderating effects of firm age in foods manufacturing SMEs in Malaysia. Procedia Economics and Finance, 35, 256-266. https://doi.org/10.1016/S2212-5671(16)00032-0 
INTERNATIONAL JOURNAL OF ACADEMIC RESEARCH IN BUSINESS AND SOCIAL SCIENCES

Vol. 8, No. 9, Sept. 2018, E-ISSN: 2222-6990 @ 2018 HRMARS

Boer, H., \& Gertsen, F. (2003). From continuous improvement to continuous innovation: a (retro)(per) spective. International Journal of Technology Management, 26(8), 805-827. https://doi.org/10.1504/IJTM.2003.003391

Boons, F., Montalvo, C., Quist, J., \& Wagner, M. (2013). Sustainable innovation, business models and economic performance: an overview. Journal of Cleaner Production, 45, 1-8. https://doi.org/10.1016/i.jclepro.2012.08.013

Bulankulama, S., \& Khatibi, A. (2014). A Theoretical Approach to the Competitive Advantage Moderating Effects of Strategies; Innovation and IT.

Carrillo-Hermosilla, J., Del Río, P., \& Könnölä, T. (2010). Diversity of eco-innovations: Reflections from selected case studies. Journal of Cleaner Production, 18(10-11), 1073-1083. https://doi.org/10.1016/i.jclepro.2010.02.014

Chen, S.-H. (2016). The influencing factors of enterprise sustainable innovation: an empirical study. Sustainability, 8(5), 425. https://doi.org/10.3390/su8050425

Economic Planning Unit. (2017). Malaysia Sustainable Development Goals Voluntary National Review 2017: High Level Political Forum.

Economic Planning Unit. (2018). Seventh Malaysia Plan, 1996 - 2000 Retrieved from http://www.epu.gov.my/en/rmk/seventh-malaysia-plan-1996-2000

Ehrenfeld, J. (2008). Sustainability by design: A subversive strategy for transforming our consumer culture: Yale University Press.

Falkenberg, J., \& Brunsæl, P. (2011). Corporate social responsibility: a strategic advantage or a strategic necessity? Journal of business ethics, 99(1), 9-16. https://doi.org/10.1007/s10551011-1161-x

Francis, P. (2015). Laudato si: On care for our common home: Our Sunday Visitor.

Fritz, M., \& Schiefer, G. (2008). Food chain management for sustainable food system development: a European research agenda. Agribusiness, 24(4), 440-452. https://doi.org/10.1002/agr.20172

Global Forum on Migration \& Development: Business Mechanism. (2016). GFMD Dhaka Summit 2016 - Business Meeting Retrieved from http://gfmdbusinessmechanism.org/event/the-businessmechanism-endorsed-as-a-permanent-feature-of-the-gfmd/

GRI. (2016). Innovation for Sustainable Development: The role of private sector collaboration Retrieved from https://www.globalreporting.org/information/news-and-presscenter/Pages/Innovation-for-Sustainable-Development-The-role-of-private-sectorcollaboration.aspx

Gutierrez, I., Alcaraz, J. M., Susaeta, L., Suarez, E., \& Pin, J. R. (2015). Managing sustainability for competitive advantage: Evidence from the hospitality industry. Working Paper WP-1115-E.

Hecht, S., Yang, A. L., Basnett, B. S., Padoch, C., \& Peluso, N. L. (2015). People in motion, forests in transition: trends in migration, urbanization, and remittances and their effects on tropical forests (Vol. 142): CIFOR.

Holden, E., Linnerud, K., \& Banister, D. (2014). Sustainable development: our common future revisited. Global environmental change, 26, 130-139. https://doi.org/10.1016/i.gloenvcha.2014.04.006

Hopkins, M. S., Townend, A., Khayat, Z., Balagopal, B., Reeves, M., \& Berns, M. (2009). The business of sustainability: what it means to managers now. MIT Sloan Management Review, 51(1), 20. 
INTERNATIONAL JOURNAL OF ACADEMIC RESEARCH IN BUSINESS AND SOCIAL SCIENCES

Vol. 8, No. 9, Sept. 2018, E-ISSN: 2222-6990 @ 2018 HRMARS

Hospers, G.-J. (2005). Joseph Schumpeter and his legacy in innovation studies. Knowledge, Technology \& Policy, 18(3), 20-37. https://doi.org/10.1007/s12130-005-1003-1

i-Scoop. (2016). Industry 4.0: the fourth industrial revolution - guide to Industrie 4.0. Retrieved from https://www.i-scoop.eu/industry-4-0/

Jones, P., Hillier, D., \& Comfort, D. (2014). Assurance of the leading UK food retailers' corporate social responsibility/sustainability reports. Corporate Governance, 14(1), 130-138. https://doi.org/10.1108/CG-03-2011-0027

Kamphof, R., Spitz, G., \& Boonstoppel, E. (2015). Financing development now and in the future: Implications for the Netherlands and beyond. Kaleidos Research, 45, 46.

Kirsty, S., Felix, D., Andrew, S., Milena, B., Jack, C., \& Robert, W. (2011). A Pocket Guide to Sustainable Development Governance (H. Stoddart Ed. Vol. 1st): Stakeholder Forum.

Kobayashi, H., Kato, M., Maezawa, Y., \& Sano, K. (2011). An R\&D management framework for ecotechnology. Sustainability, 3(8), 1282-1301. https://doi.org/10.3390/su3081282

Kooijman-van Dijk, A. L., \& Clancy, J. (2010). Impacts of electricity access to rural enterprises in Bolivia, Tanzania and Vietnam. Energy for Sustainable Development, 14(1), 14-21.

Leach, M., Rockström, J., Raskin, P., Scoones, I., Stirling, A., Smith, A., . . . Arond, E. (2012). Transforming innovation for sustainability. Ecology and Society, 17(2). https://doi.org/10.5751/ES-04933-170211

Lin, C.-Y., \& Kuo, T.-H. (2007). The mediate effect of learning and knowledge on organizational performance. Industrial Management \& Data Systems, 107(7), 1066-1083. https://doi.org/10.1108/02635570710816748

Shahbudin, A. S. M., Nejati, M., \& Amran, A. (2011). Sustainability-based knowledge management performance evaluation system (SKMPES): linking the higher learning institutes with the bottom billions. African Journal of Business Management, 5(22), 8843.

Mokthsim, N., \& Salleh, K. O. (2014). Malaysia's Efforts toward Achieving a Sustainable Development: Issues, Challenges and Prospects. Procedia-Social and Behavioral Sciences, 120, 299-307. https://doi.org/10.1016/i.sbspro.2014.02.107

Motesharrei, S., Rivas, J., \& Kalnay, E. (2014). Human and nature dynamics (HANDY): Modeling inequality and use of resources in the collapse or sustainability of societies. Ecological Economics, 101, 90-102. https://doi.org/10.1016/j.ecolecon.2014.02.014

Radieah, M. N., Koshy, K. C., \& Ibrahim, K. (2015). Financing for Sustainable Development: Reflections on the Malaysian Perspective against the Six Capital Types Proposed by United Nations Sustainable Development Solutions Network. Journal of Human Resource and Sustainability Studies, 3(03), 141. https://doi.org/10.4236/ihrss.2015.33019

OECD. (2011). Towards green growth: A summary for policy makers Retrieved from https://www.oecd.org/greengrowth/48012345.pdf

Porter, M., \& Kramer, M. (2011). Creating Shared Value" Harvard Business Review, January 2011.

Porter, M. E. (2000). Location, competition, and economic development: Local clusters in a global economy. Economic development quarterly, 14(1), 15-34. https://doi.org/10.1177/089124240001400105 
INTERNATIONAL JOURNAL OF ACADEMIC RESEARCH IN BUSINESS AND SOCIAL SCIENCES Vol. 8, No. 9, Sept. 2018, E-ISSN: 2222-6990 @ 2018 HRMARS

Rafika, K., Rym, K., Souad, S. B., \& Youcef, L. (2016). A public actor awareness for sustainable development. Procedia-Social and Behavioral Sciences, 216, 151-162. https://doi.org/10.1016/i.sbspro.2015.12.022

Raynolds, L. T., Murray, D., \& Wilkinson, J. (2007). Fair trade: The challenges of transforming globalization: Routledge.

Sánchez-Medina, P. S., Corbett, J., \& Toledo-López, A. (2011). Environmental innovation and sustainability in small handicraft businesses in Mexico. Sustainability, 3(7), 984-1002. https://doi.org/10.3390/su3070984

Schaltegger, S., \& Wagner, M. (2011). Sustainable entrepreneurship and sustainability innovation: categories and interactions. Business strategy and the environment, 20(4), 222-237. https://doi.org/10.1002/bse.682

Seghezzo, L. (2009). The five dimensions of sustainability. Environmental politics, 18(4), 539-556. https://doi.org/10.1080/09644010903063669

Shamsul, A. B. (2012). Wawasan 2020: Negara Teguh, Bangsa Terus Dibina. Paper presented at the Seminar Wawasan 2020: Transformasi Malaysia, Kuala Lumpur, Malaysia. https://www.researchgate.net/publication/276207395 Wawasan 2020 Negara Teguh Ba ngsa Terus Dibina

Smeds, R., \& Boer, H. (2004). Continuous innovation and learning in industrial organizations. Knowledge and process management, 11(4), 225-227. https://doi.org/10.1002/kpm.213

Smith, A., Stirling, A., \& Berkhout, F. (2005). The governance of sustainable socio-technical transitions. Research policy, 34(10), 1491-1510. https://doi.org/10.1016/i.respol.2005.07.005

Smith, L., \& Ball, P. (2012). Steps towards sustainable manufacturing through modelling material, energy and waste flows. International Journal of Production Economics, 140(1), 227-238. https://doi.org/10.1016/j.ijpe.2012.01.036

Solmecke, U. (2017). Multinational Enterprises and the'One Belt, One road'Initiative: Sustainable Development and Innovation in a Post-Crisis Global Environment. The Copenhagen Journal of Asian Studies, 34(2), 9-27. https://doi.org/10.22439/cjas.v34i2.5304

Teece, D. J., Pisano, G., \& Shuen, A. (1997). Dynamic capabilities and strategic management. Strategic management journal, 18(7), 509-533. https://doi.org/10.1002/(SICl)10970266(199708)18:7<509::AID-SMJ882>3.0.CO;2-Z

Terrapon-Pfaff, J., Dienst, C., König, J., \& Ortiz, W. (2014). How effective are small-scale energy interventions in developing countries? Results from a post-evaluation on project-level. Applied Energy, 135, 809-814. https://doi.org/10.1016/j.apenergy.2014.05.032

UCLG. (2015). The Sustainable Development Goals: What Local Governments Need to Know. Retrieved from https://www.uclg.org/sites/default/files/the sdgs what localgov need to know 0.pdf

UNESCO. (2014). UNESCO Education Strategy 2014-2021. Paris, France: United Nations Educational, Scientific and Cultural Organization.

United Nations. (2015a). Resolution adopted by the General Assembly on 25 September 2015. Retrieved from www.un.org/en/development/.../generalassembly/.../globalcompact/A RES $701 \mathrm{E}$ 
INTERNATIONAL JOURNAL OF ACADEMIC RESEARCH IN BUSINESS AND SOCIAL SCIENCES

Vol. 8, No. 9, Sept. 2018, E-ISSN: 2222-6990 (C) 2018 HRMARS

United Nations. (2015b). Transforming our World: The 2030 Agenda for Sustainable Development. Retrieved from https://sustainabledevelopment.un.org/about

United Nations. (2016). First annual Multi-stakeholder Forum on Science, Technology and Innovation for the Sustainable Development Goals. Retrieved from

United Nations Global Impact. (2016). UN Global Compact Leaders Summit 2016. Retrieved from https://www.unglobalcompact.org/take-action/events/411-un-global-compact-leaderssummit-2016

Vinarski-Peretz, H., \& Carmeli, A. (2011). Linking care felt to engagement in innovative behaviors in the workplace: The mediating role of psychological conditions. Psychology of Aesthetics, Creativity, and the Arts, 5(1), 43. https://doi.org/10.1037/a0018241

Waite, A. M. (2014). Leadership's influence on innovation and sustainability: A review of the literature and implications for HRD. European Journal of Training and Development, 38(1/2), 15-39. https://doi.org/10.1108/EJTD-09-2013-0094

Waples, E. P., Friedrich, T. L., \& Shelton, P. M. (2011). Closing Comments on 'Leading for Innovation' We've Only Just Begun. Advances in Developing Human Resources, 13(3), 406-413. https://doi.org/10.1177/1523422311424719

Whiteman, G., Hope, C., \& Wadhams, P. (2013). Climate science: Vast costs of Arctic change. Nature, 499(7459), 401. https://doi.org/10.1038/499401a

World Business Council for Sustainable Development. (2010). Vision 2050: The new agenda for business. Retrieved from https://www.wbcsd.org/Overview/Aboutus/Vision2050/Resources/Vision-2050-The-new-agenda-for-business

Yang, C.-L., Lin, S.-P., Chan, Y.-h., \& Sheu, C. (2010). Mediated effect of environmental management on manufacturing competitiveness: an empirical study. International Journal of Production Economics, 123(1), 210-220. https://doi.org/10.1016/j.ijpe.2009.08.017

Yang, M. G. (2013). Developing a focal firm's sustainable supply chain framework: Drivers, orientation, practices and performance outcomes: The University of Toledo. 